\title{
Optimal fluorite/gypsum mineralizer ratio in Portland cement clinkering
}

\author{
J.I. Tobón ${ }^{\mathrm{a} \bowtie}$, M.F. Díaz-Burbano ${ }^{\mathrm{b}}$, O.J. Restrepo-Baena ${ }^{\mathrm{a}}$ \\ a. Departamento de Materiales y Minerales. Universidad Nacional de Colombia (Medellín, Colombia) \\ b. I\&D Materiales Cementos Argos S.A. (Medellín, Colombia) \\ $\triangle$ jitobon@unal.edu.co
}

\begin{abstract}
This paper presents an analysis of the joint effect of fluorite and gypsum as mineralizers in the manufacture of Portland cement. A laboratory- scale Box-Behnken statistical design was used to quantify the effects of the explanatory variables fluorite content $(0.00,0.25,0.50$, and $0.75 \%)$, fluorite/gypsum ratio $(2 / 15$, $1 / 3$ and $8 / 15)$, and clinkering temperature $\left(1250,1300\right.$, and $\left.1350^{\circ} \mathrm{C}\right)$ on the response variable free $\mathrm{CaO}$ content in the clinker produced. The clinker was characterized by the ethylene method, XRD, DSC and optical microscopy. Free $\mathrm{CaO}$ decreases of $81 \%$ and $56 \%$ were found in the mineralized clinker, compared to the same clinker without mineralizers, at $1300{ }^{\circ} \mathrm{C}$ and $1250^{\circ} \mathrm{C}$, respectively. Petrographic analysis showed that at lower temperatures, the amount of alite in the mineralized clinker was higher than the amount of alite in the clinker without mineralizers. The best condition was found for the fluorite/gypsum ratio of $2 / 15$.
\end{abstract}

KEYWORDS: Mineralizers; Fluorite; Gypsum; Clinker; Clinkering

Citation/Citar como: Tobón, J.I.; Díaz-Burbano, M.F.; Restrepo-Baena, O.J. (2016) Optimal fluorite/gypsum mineralizer ratio in Portland cement clinkering. Mater. Construcc. 66 [322], e086 http://dx.doi.org/10.3989/mc.2016.05515.

RESUMEN: Relación óptima de los mineralizadores fluoritalyeso en la clinkerización del cemento Portland. Este artículo presenta el efecto combinado de la fluorita y el yeso como mineralizadores. Se usó el diseño experimental estadístico Box-Behnken, a escala de laboratorio, para cuantificar el efecto de la fluorita en porcentajes de $0.00,0.25,0.50$ y $0.75 \%$; relaciones fluorita/yeso de $2 / 15,1 / 3$ y $8 / 15$; con temperaturas de clinkerización de 1250,1300 y $1350{ }^{\circ} \mathrm{C}$ y la cal libre como variable de respuesta. El clínker producido fue caracterizado midiendo el contenido de cal libre por el método de etileno, DRX, DSC y microscopía óptica. Se encontró un descenso de la cal libre del 81 y $56 \%$ en el clinker mineralizado en comparación con el clinker sin mineralizadores a 1300 y $1250^{\circ} \mathrm{C}$ respectivamente. El análisis petrográfico mostró que la cantidad de alita en el clinker mineralizado a bajas temperaturas es más alta que en el clinker sin mineralizadores. La mejor condición se encontró para la relación fluorita/yeso de 2/15.

PALABRAS CLAVE: Mineralizadores; Fluorita; Yeso; Clinker; Clinkerización

Copyright: (C) 2016 CSIC. This is an open-access article distributed under the terms of the Creative Commons Attribution-Non Commercial (by-nc) Spain 3.0 License.

\section{INTRODUCTION}

Portland cement is obtained by comminuting clinkers and adding one or more forms of calcium sulfate. The addition of other raw materials (pozzolans and fillers) is allowed, provided that they do not negatively affect the properties of the resulting cement (1). In the Portland cement manufacturing process, fuel costs during the clinkering stage account for approximately $30-50 \%$ of cement production costs (2). 
This percentage is due to the high kiln operation temperature, which is around $1500^{\circ} \mathrm{C}$. This implies high fossil fuel-based energy consumption, greenhouse gas emissions, a short useful life of the refractory material, and high electricity usage, among other issues (3-6).

One of the most significant environmental problems of the cement industry is that $0.73-0.99$ tons of $\mathrm{CO}_{2}$ are emitted per ton of cement manufactured, depending on the clinker/cement ratio and other factors. From these data, some researchers have estimated that the cement industry is responsible for $5-7 \%$ of all global anthropogenic emissions $(7,8)$.

Many solutions have been proposed to address these drawbacks. These include: the use of energy alternatives (9), technological developments in the clinkering process (4), the use of by-products as raw materials $(6,9-11)$, the use of mineralizers and fluxes to reduce the clinkering temperature and accelerate the formation of the main mineral phases $(10,12,13)$, the use of mineral additions to the cement (puzzolans and fillers) to lower the clinker/ cement ratio (14), alternative cements $(10,15,16)$, and the development of high-performance concrete (17), among others. The use of mineralizers has proven to be a very good option in this regard, but it is not yet fully understood.

Mineralization accelerates the formation process of the main constitutive phases of the clinker $\left(\mathrm{C}_{3} \mathrm{~S}\right.$ and $\left.\mathrm{C}_{2} \mathrm{~S}\right)$ by changing their thermodynamic stability. This allows them to appear at a lower temperature $(12,13)$. The inclusion of minor elements from mineralizers can lead to modifications in the hydraulic activity of silicates, due to the formation of solid solutions or changes in their structure (18).

Mineralizers can act as fluxes. A flux is a material with high heat transfer that melts at a lower temperature than the compound of interest, in this case the calcium silicates. Fluxes decrease the temperature at which aluminium and iron oxide melt. Furthermore, they decrease the viscosity and surface tension of the liquidus that facilitate the transport of reactants and allow silicates to form at lower temperatures $(12,13)$. This makes it possible to use less coal and thus emit lower levels of $\mathrm{CO}_{2}, \mathrm{NO}_{\mathrm{x}}$, and $\mathrm{SO}_{\mathrm{x}}$ into the atmosphere.

The mineralizers and fluxes studied in the clinkering process include Titanium, Manganese, Silver, Iron, Zinc, Chrome, Nickel, Copper (9, 19-22), phosphate gypsum (23), sulfate, fluorite (24-27), $\mathrm{MgO}(28,29)$, and potassium fluoride (24).

In general, mineralizers are responsible for the following $(26,30,31)$ :

A decrease in:

- Clinkering temperature and liquid phase formation;

- Caloric consumption;
- Gas emissions $\left(\mathrm{CO}_{2}, \mathrm{SO}_{\mathrm{x}}, \mathrm{NO}_{\mathrm{x}}\right)$, due to decreased fuel usage;

- Residence time inside the kiln, due to the formation of phases at a lower temperature (with the same heating rate of a process without mineralization);

- Energy consumption in the milling process, because a more pulverized clinker is produced;

- Costs, due to decreased fuel usage.

An increase in:

- $\mathrm{C}_{3} \mathrm{~S}$ content, due to increased ionic mobility;

- $\mathrm{C}_{3} \mathrm{~S}$ and $\mathrm{C}_{2} \mathrm{~S}$ reactivity, due to the crystalline structure formed by trace elements;

- Final product strength properties, due to the new crystalline structure;

- Cement mill production, because the higher porosity of the clinker produced makes it easier to mill;

- Service life of furnace firebrick, due to the lower working temperatures.

Most mineralizers employed contain fluorine, due to its electronegativity. The most common of these are fluorides and fluoro-silicates $(12,13)$.

$\mathrm{CaF}_{2}$ is the material that is most used at a global level, because it acts as both a mineralizer and a flux. It lowers the alite formation temperature by improving solid-state diffusions (28). $\mathrm{CaF}_{2}$ also reduces the formation temperature, viscosity and surface tension of the liquid phase (28). At bench/ lab scale, fluorite causes the clinkering temperature to decrease by around $130{ }^{\circ} \mathrm{C}(26)$. When $0.4 \mathrm{wt} . \%$ $\mathrm{CaF}_{2}$ is added to the clinker, the amount of alite increases and the mechanical properties improve by about 20\% (32). According to Chatterjee (4), this improvement in cement strength occurs because the fluorine enables the alite to change from a monoclinic $\left(\mathrm{M}_{3}\right)$ to a rhombohedral polymorph.

The use of gypsum in some cement factories has had positive environmental and energetic results (25). However, a disadvantage of using sulfate as a mineralizer is that it causes belite stabilization, which inhibits alite formation $(4,10)$. This effect is counteracted if sulfate is combined with fluoride (33).

The use of $\mathrm{CaF}_{2}$ and $\mathrm{CaSO}_{4} \cdot 2 \mathrm{H}_{2} \mathrm{O}$ in clinkering can allow the maximum clinkering temperature decreases to $1350{ }^{\circ} \mathrm{C}(34)$ due to the formation of fluorellestadite $\left(3 \mathrm{C}_{2} \mathrm{~S} \mathrm{CaSO}_{4} \cdot \mathrm{CaF}_{2}\right)$, which is an intermediate phase in the liquid phase formation (30). For this reason, these mineralizers are capable of partially substituting for $\mathrm{C}_{3} \mathrm{~A}$ and $\mathrm{C}_{4} \mathrm{AF}(35,36)$. This combination has been so successful that some researchers suggest that other mineralizers without $\mathrm{F}$ and $\mathrm{SO}_{3}$ are not likely to be put into actual use (37).

Other researchers have shown that coal consumption in the production of white cement can be reduced by $9 \%$ by using a $\mathrm{CaF}_{2}-\mathrm{CaSO}_{4}$ mixture (30). It is known that when fluorite and gypsum are 
combined as mineralizers, the fluorite accelerates alite formation, while the gypsum diminishes the liquid phase formation temperature. Additionally, fluorite and gypsum are natural minerals that are readily available for industrial use.

In the present research, we determined the optimal fluorite/gypsum ratio for reaching the maximum decrease in clinkering temperature for gray cement production.

\section{EXPERIMENTAL}

Clinkers with and without mineralizers were produced in the laboratory with reagent oxides, at different temperatures $\left(1250,1300\right.$, and $\left.1350^{\circ} \mathrm{C}\right)$.

Raw materials were characterized by X-Ray fluorescence (XRF) to determine their chemical composition.

Samples were formulated with $\mathrm{CaO}, \mathrm{SiO}_{2}$, $\mathrm{Al}_{2} \mathrm{O}_{3}, \mathrm{Fe}_{2} \mathrm{O}_{3}$ and with the mineralizers $\mathrm{CaF}_{2}$ and $\mathrm{CaSO}_{4} \cdot 2 \mathrm{H}_{2} \mathrm{O}$. A reference clinker was produced in the laboratory for each temperature, taking into consideration the lime saturation factor $(\mathrm{LSF}=95.18)$, silica modulus $(\mathrm{SM}=2.51)$ and alumina modulus $(\mathrm{AM}=1.59)$. Fluorite and gypsum were added to raw meal in percentage in weight, with fluorite in $0.25,0.50$, and 0.75 wt. $\%$ and a fluorite/gypsum ratio of $2 / 15,8 / 15$, and $1 / 3$ (Table 1 ).

Afterwards, the raw meal was homogenized and spheres with a diameter of $2.5 \mathrm{~cm}$ were formed using deionized water.

Clinker formation was studied mainly on the basis of free lime content in the burned samples.

TABLE 1. Matrix tests according to the Box-Behnken design

\begin{tabular}{lccc}
\hline Test & $\begin{array}{c}\mathbf{C a F}_{2} / \mathbf{C a S O}_{\mathbf{4}} \cdot \mathbf{2} \mathbf{H}_{\mathbf{2}} \mathbf{O} \\
\text { Ratio }\end{array}$ & $\begin{array}{c}\text { Mineralizer } \\
\left(\mathbf{C a F}_{2}\right)\end{array}$ & Temperature ${ }^{\circ} \mathbf{C}$ \\
\hline 1 & $2 / 15$ & 0.25 & 1300 \\
2 & $2 / 15$ & 0.75 & 1300 \\
3 & $8 / 15$ & 0.25 & 1300 \\
4 & $8 / 15$ & 0.75 & 1300 \\
5 & $2 / 15$ & 0.50 & 1250 \\
6 & $2 / 15$ & 0.50 & 1350 \\
7 & $8 / 15$ & 0.50 & 1250 \\
8 & $8 / 15$ & 0.50 & 1300 \\
9 & $1 / 3$ & 0.25 & 1250 \\
10 & $1 / 3$ & 0.25 & 1350 \\
11 & $1 / 3$ & 0.75 & 1250 \\
12 & $1 / 3$ & 0.75 & 1350 \\
13 & $1 / 3$ & 0.50 & 1300 \\
14 & $1 / 3$ & 0.50 & 1300 \\
15 & $1 / 3$ & 0.50 & 1300 \\
Central 1 & $1 / 3$ & 0.50 & 1300 \\
Central 2 & $1 / 3$ & 0.50 & 1300 \\
Central 3 & $1 / 3$ & 0.50 & 1300 \\
\hline
\end{tabular}

This is the most widely used procedure because the calcium oxide, initially formed by $\mathrm{CaCO}_{3}$ dissociation, is gradually consumed by the clinker phases (20). The free lime was measured with the ethylene method; optical microscopy; Differential Scanning Calorimetry (DSC); and X-Ray Diffraction (XRD).

\subsection{Materials}

Reagent grade $\mathrm{CaO}, \mathrm{SiO}_{2}, \mathrm{Al}_{2} \mathrm{O}_{3}$, and $\mathrm{Fe}_{2} \mathrm{O}_{3}$ were used. Aldrich, Carlo Erba and Sigma supplied these oxides.

Fluorite $\left(\mathrm{CaF}_{2}\right)$ with $80.99 \%$ purity was obtained from Minera Las Cuevas (Mexico) and Gypsum $\left(\mathrm{CaSO}_{4} \cdot 2 \mathrm{H}_{2} \mathrm{O}\right)$ was obtained from Spain.

\subsection{Methods}

\subsubsection{Chemical analysis}

X-ray fluorescence (XRF) was performed on raw materials using beads fused with lithium boride $\left(\mathrm{B}_{4} \mathrm{Li}_{2} \mathrm{O}_{7}\right)$. The equipment used was a Thermo ARL 9800 XP spectrometer.

\subsubsection{High temperature furnace}

A BLF 17/3 Carbolite furnace was used to produce the clinker, with a maximum temperature of $1700{ }^{\circ} \mathrm{C}$ and $220 \mathrm{~V}$. The heating rate for all tests was the same $\left(10^{\circ} \mathrm{C} / \mathrm{min}\right)$; only the maximum clinkering temperature changed. The residence time for each sample at higher temperatures was always 40 minutes. Clinkering processes were carried out in an artisanal crucible made from refractory brick, reference ALMAG AF of Refratechnik. When the heating process for each test was completed, the crucible with the red hot sample was removed from the furnace. All clinkers were cooled with air from a compressor at 5 psi for 10 minutes to reach a final temperature of approximately $40^{\circ} \mathrm{C}$.

\subsection{3. $X$-ray diffraction $(X R D)$}

The XRD patterns were collected in a PANalytical X'Pert PRO MPD, with a Cu source, Bragg-Brentano configuration, a range from $15^{\circ}$ to $70^{\circ}$ of 2 theta, an $\mathrm{X}$ Celerator detector step of $0.016^{\circ}$ and an accumulation time of more than 10000 counts in the main peak. The mineralogical analysis was performed by Rietveld methodology using High Score Plus software and the Inorganic Crystal Structure Database (ICSD).

\subsubsection{Differential Scanning Calorimetry (DSC)}

This was performed using SDT Q600 equipment with an inert atmosphere of $\mathrm{N}_{2}$, an alumina melting pot of $90 \mathrm{~mL}$, a scan rate of $20 \% \mathrm{~min}$ and a temperature ramp from $25^{\circ} \mathrm{C}$ to $1500{ }^{\circ} \mathrm{C}$. 


\subsubsection{Optical Microscopy}

An OLYMPUS MMQC-005 petrographic microscope, model BX41, was used to qualitatively analyze the clinker obtained, in order to identify the phases formed. The petrographic analysis was performed with reflected light on polished specimens etched with nital (nitric acid at 1\% in isopropyl alcohol).

\subsubsection{Measurement of free lime with the ethylene method}

This test was performed to provide an indicator of the degree of clinkering in the material. Free lime was measured by dissolving $\mathrm{CaO}$ in a methanol:ethylene glycol (1:2) mixture at a temperature of $80{ }^{\circ} \mathrm{C}$ with constant agitation. After the solution was filtered, it was titrated with $0.1 \mathrm{~N}$ hydrochloric acid using bromocresol green - Methyl red as a mixed indicator.

\subsubsection{Experimental design}

A Box-Behnken statistical design was used in this study. The factors considered were fluorite content, fluorite/gypsum ratio and clinkering temperature. The response variable was free lime. The levels of each factor were taken from previous studies on mineralization $(26,35)$. This study explored the effects of fluorite and gypsum at low and high levels. Table 1 shows the matrix design for randomized trials. The central points are additional experimental runs located at a midpoint between the lower and higher level of all factors. This is done to estimate experimental error and adjust the model.

\section{RESULTS AND DISCUSSION}

\subsection{Characterization of raw materials}

The X-Ray Fluorescence (XRF) results showed that the oxides and mineralizers used had high purity (Table 2). This enables a better understanding of the effect of fluorite and gypsum on clinkering temperature and prevents that mineralizers interact with other compounds as contaminants.

\subsection{Characterization of clinkers}

\subsubsection{Measurement of free $\mathrm{CaO}$ in the clinker: Free} $\mathrm{CaO}$ determined by titration is shown in Table 3

The results obtained were grouped by clinkering temperature, as follows (Figures 1, 2, and 3):

At $1300{ }^{\circ} \mathrm{C}$ and $1250^{\circ} \mathrm{C}$ (Figures 2 and 3 ) all the formulations with mineralization had less free $\mathrm{CaO}$ than the reference sample, as a result of more efficient
TABLE 2. Chemical analysis of raw materials by XRF

\begin{tabular}{lcccccc}
\hline Oxide (\%) & $\mathrm{Fe}_{2} \mathbf{O}_{3}$ & $\mathrm{Al}_{2} \mathbf{O}_{3}$ & $\mathbf{S i O}_{2}$ & $\mathbf{C a O}$ & $\mathbf{C a F}_{2}$ & $\mathbf{C a S O}_{4} .2 \mathbf{H}_{2} \mathbf{O}$ \\
\hline $\mathrm{SiO}_{2}$ & - & - & 98.65 & - & 4.75 & 1.58 \\
$\mathrm{Al}_{2} \mathrm{O}_{3}$ & - & 93.80 & 0.03 & - & 0.42 & 0.57 \\
$\mathrm{Fe}_{2} \mathrm{O}_{3}$ & 93.37 & - & 0.05 & - & 0.10 & 0.18 \\
$\mathrm{CaO}$ & - & 0.21 & 0.39 & 85.81 & 43.50 & 33.50 \\
$\mathrm{MgO}$ & - & - & - & - & - & 0.20 \\
$\mathrm{SO}_{3}$ & - & 0.32 & - & 0.82 & 0.05 & 42.10 \\
$\mathrm{~F}$ & - & - & - & - & 47.80 & - \\
$\mathrm{Na}_{2} \mathrm{O}$ & - & 0.02 & - & - & - & - \\
$\mathrm{K}_{2} \mathrm{O}$ & - & - & 0.08 & - & 0.14 & 0.08 \\
$\mathrm{MnO}$ & - & 0.01 & 0.01 & - & - & 0.01 \\
$\mathrm{P}_{2} \mathrm{O}_{5}$ & - & - & - & 0.05 & 0.18 & 0.05 \\
$\mathrm{Sr}$ & - & - & - & - & - & 0.09 \\
$\mathrm{TiO}_{2}$ & - & 0.01 & 0.04 & - & 0.14 & 0.01 \\
$\mathrm{Cr}_{2} \mathrm{O}_{3}$ & - & - & - & - & 0.01 & - \\
$\mathrm{L} . \mathrm{O} . \mathrm{I}$ & 0.25 & 5.81 & 0.76 & 12.33 & 3.91 & 22.30 \\
\hline
\end{tabular}

TABLE 3. Matrix tests according to the Box-Behnken design, and free lime obtained

\begin{tabular}{lcccc}
\hline Test & $\begin{array}{c}\mathbf{C a F}_{2} / \mathbf{C a S O}_{\mathbf{4}} \cdot \\
\mathbf{2 H}_{2} \mathbf{O} \text { Ratio }\end{array}$ & $\begin{array}{c}\text { Mineralizer } \\
\left(\mathbf{C a F}_{\mathbf{2}}\right)\end{array} \mathbf{\%}$ & $\begin{array}{c}\text { Temperature } \\
{ }^{\circ} \mathbf{C}\end{array}$ & $\begin{array}{c}\text { Free } \\
\mathbf{C a O} \text { in } \\
\mathbf{c l i n k e r}\end{array}$ \\
\hline 1 & $2 / 15$ & 0.25 & 1300 & 6.95 \\
2 & $2 / 15$ & 0.75 & 1300 & 1.93 \\
3 & $8 / 15$ & 0.25 & 1300 & 8.15 \\
4 & $8 / 15$ & 0.75 & 1300 & 4.29 \\
5 & $2 / 15$ & 0.50 & 1250 & 5.42 \\
6 & $2 / 15$ & 0.50 & 1350 & 2.24 \\
7 & $8 / 15$ & 0.50 & 1250 & 8.28 \\
8 & $8 / 15$ & 0.50 & 1300 & 2.54 \\
9 & $1 / 3$ & 0.25 & 1250 & 10.39 \\
10 & $1 / 3$ & 0.25 & 1350 & 4.04 \\
11 & $1 / 3$ & 0.75 & 1250 & 5.49 \\
12 & $1 / 3$ & 0.75 & 1350 & 3.14 \\
13 & $1 / 3$ & 0.50 & 1300 & 6.24 \\
14 & $1 / 3$ & 0.50 & 1300 & 5.32 \\
15 & $1 / 3$ & 0.50 & 1300 & 5.20 \\
Central 1 & $1 / 3$ & 0.50 & 1300 & 4.70 \\
Central 2 & $1 / 3$ & 0.50 & 1300 & 5.22 \\
Central 3 & $1 / 3$ & 0.50 & 1300 & 5.20 \\
\hline & & & &
\end{tabular}

clinkering (the reaction of the raw materials with the mineralizers increased alite production). The reference sample at $1350{ }^{\circ} \mathrm{C}$ (Figure 1) had lower free $\mathrm{CaO}$ than the mixtures with fluorite and gypsum at the same temperature. One hypothesis to explain this behavior is that when the samples reached $1350{ }^{\circ} \mathrm{C}$, fluorine volatilization occurred and this became a 


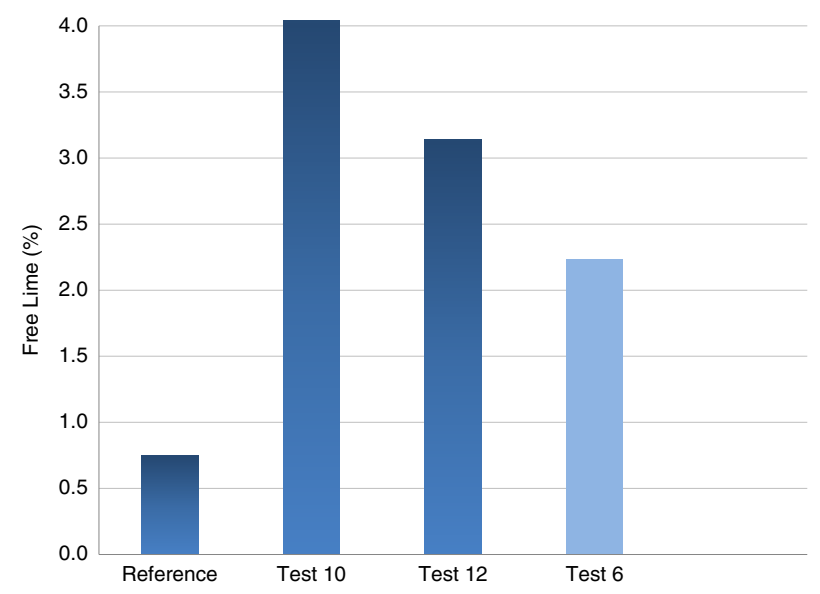

Figure 1. Free $\mathrm{CaO}$ at $1350^{\circ} \mathrm{C}$.

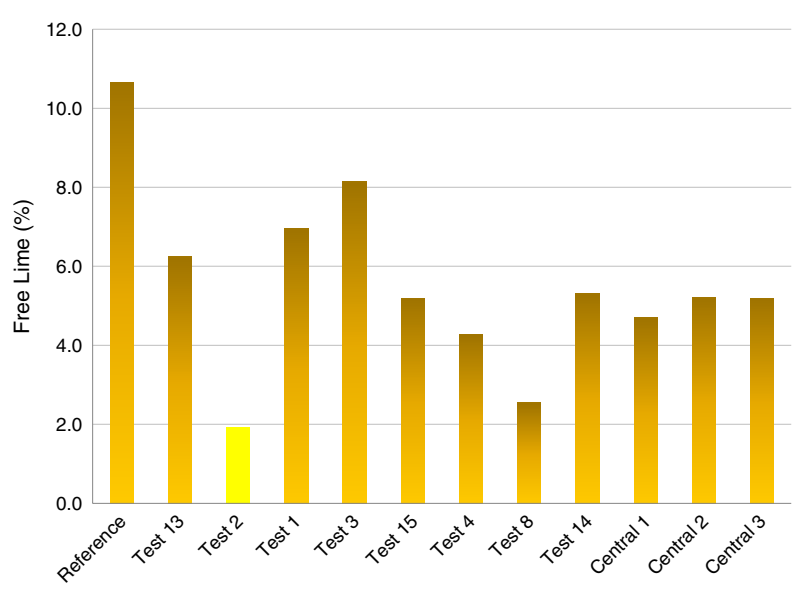

Figure 2. Free $\mathrm{CaO}$ at $1300{ }^{\circ} \mathrm{C}$.

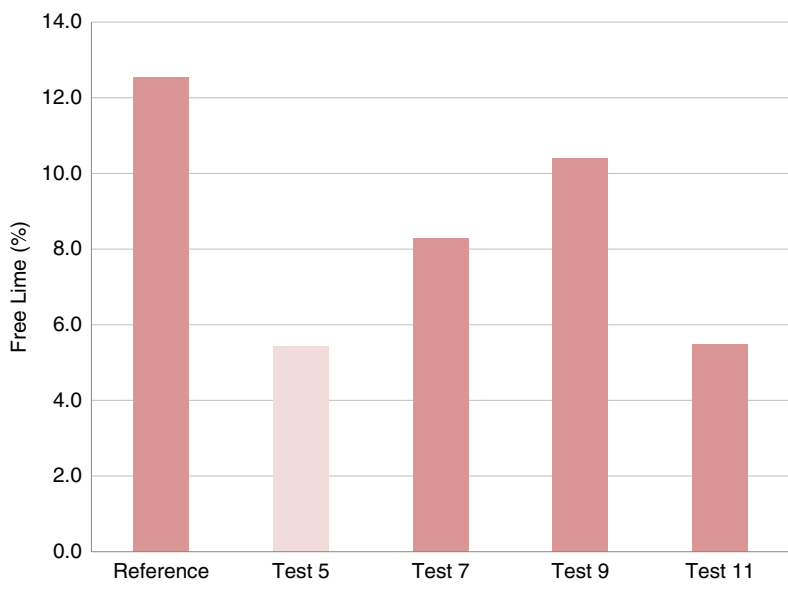

Figure 3. Free $\mathrm{CaO}$ at $1250^{\circ} \mathrm{C}$.

limiting factor for mineralization. It is well known that fluorine evaporates easily at high temperatures, like alkalies and sulfates (28).
The tests that showed the lowest free $\mathrm{CaO}$ (tests 6, 2, and 5) are highlighted in Figures 1, 2, and 3. These formulations had a $\mathrm{CaF}_{2} / \mathrm{CaSO}_{4} \cdot 2 \mathrm{H}_{2} \mathrm{O}$ ratio of $2 / 15$. The high fluorite content $(0.75$ and $0.5 \%$ ) facilitated the reaction of $\mathrm{C}_{2} \mathrm{~S}$ with $\mathrm{CaO}$ to form $\mathrm{C}_{3} \mathrm{~S}$.

In Figure 2 and Table 3, when comparing the reference at $1300{ }^{\circ} \mathrm{C}$ (without mineralization) with test $2\left(\mathrm{CaF}_{2} / \mathrm{CaSO}_{4} \cdot 2 \mathrm{H}_{2} \mathrm{O}=2 / 15\right.$, temperature $=1300{ }^{\circ} \mathrm{C}$, and fluorite $=0.75$ ) an $81 \%$ decrease in free $\mathrm{CaO}$ can be observed in the mineralized clinker. Moreover, in Figure 3 and Table 3, when comparing the reference at $1250^{\circ} \mathrm{C}$ with test $5\left(\mathrm{CaF}_{2} / \mathrm{CaSO}_{4} \cdot 2 \mathrm{H}_{2} \mathrm{O}=2 / 15\right.$, temperature $=1250{ }^{\circ} \mathrm{C}$, and fluorite $=0.50$ ) a $56 \%$ decrease in free $\mathrm{CaO}$ can be observed. Thus, the $\mathrm{CaF}_{2} / \mathrm{CaSO}_{4} \cdot 2 \mathrm{H}_{2} \mathrm{O}=2 / 15$ ratio plays an important role in reducing clinkering temperature, i.e., in the formation of calcium silicates $\left(\mathrm{C}_{2} \mathrm{~S}\right.$ and $\left.\mathrm{C}_{3} \mathrm{~S}\right)$. The effect of the $2 / 15$ fluorite/gypsum ratio on the clinker was more noticeable at $1300{ }^{\circ} \mathrm{C}$.

\subsection{2. $X$-ray diffraction $(X R D)$}

Table 4 and Figures 4, 5, and 6 show the identification and quantification of clinker phases with and without mineralizers. In order to ensure a good fit of the calculated pattern to the observed data, we looked for a weighted-profile R-value (Rwp) below $10 \%$ for all samples.

Figure $4\left(1350{ }^{\circ} \mathrm{C}\right)$ and Table 4 show that alite content decreased and belite content increased when mineralizers were present. This is consistent with the higher free lime content found in these samples by titration, which means that the clinkering process for the mineralized clinker was incomplete at this temperature.

Figures 5 and $6\left(1300^{\circ} \mathrm{C}\right.$ and $\left.1250{ }^{\circ} \mathrm{C}\right)$ and Table 4 show that alite content increased and belite content decreased when mineralizers were present. This is consistent with the lower free lime content found in these samples by titration, which means that the mineralized clinker was more sintered at these temperatures. This result is consistent with those of researchers including Akin (21), who found that $\mathrm{C}_{3} \mathrm{~S}$ formation increased with the addition of fluorine.

The free $\mathrm{CaO}$ of the mineralized clinker was lower than that of the clinker without fluorite and gypsum (Figures 5 and 6). This indicates that the mineralizers improved the clinkering process.

\subsubsection{Differential Scanning Calorimetry (DSC)}

Figures 7, 8, and 9 show that the raw material with mineralizers presented clinkering $\left(\mathrm{C}_{3} \mathrm{~S}\right.$ and $\mathrm{C}_{2} \mathrm{~S}$ formation) at lower temperatures than the raw material without mineralizers.

The DSC technique also showed that the mineralizers had the greatest effect at temperatures between $1250{ }^{\circ} \mathrm{C}$ and $1300{ }^{\circ} \mathrm{C}$. 
TABLE 4. Mineralogical analysis of the clinker with and without mineralization (XRD)

\begin{tabular}{|c|c|c|c|c|c|c|}
\hline & \multicolumn{6}{|c|}{ Quantitative analysis of clinkers (wt.\%) } \\
\hline & $\begin{array}{l}1350{ }^{\circ} \mathrm{C} \text { without } \\
\text { Mineralizer }\end{array}$ & $\begin{array}{c}1350{ }^{\circ} \mathrm{C} \text { with } \\
\text { Mineralizer Test } 6\end{array}$ & $\begin{array}{c}1300{ }^{\circ} \mathrm{C} \text { without } \\
\text { Mineralizer }\end{array}$ & $\begin{array}{c}1300{ }^{\circ} \mathrm{C} \text { with } \\
\text { Mineralizer Test } 2\end{array}$ & $\begin{array}{l}1250^{\circ} \mathrm{C} \text { without } \\
\text { Mineralizer }\end{array}$ & $\begin{array}{c}1250{ }^{\circ} \mathrm{C} \text { with } \\
\text { Mineralizer Test } 5\end{array}$ \\
\hline $\mathrm{C}_{3} \mathrm{~S}$ & 55.0 & 44.7 & 37.6 & 48.2 & 29.2 & 39.9 \\
\hline$\beta-\mathrm{C}_{2} \mathrm{~S}$ & 24.1 & 36.5 & 41.8 & 32.1 & 49.4 & 36.1 \\
\hline $\mathrm{C}_{3} \mathrm{~A}$ cubic & 5.1 & 3.3 & - & 2.4 & - & 1.8 \\
\hline $\mathrm{C}_{3} \mathrm{~A}$ orthorhombic & 0.4 & - & 3.0 & - & 3.9 & - \\
\hline $\mathrm{C}_{4} \mathrm{AF}$ & 14.2 & 13.9 & 9.2 & 15.3 & 5.7 & 16.8 \\
\hline $\mathrm{CaO}$ & 0.4 & 0.4 & 2.4 & - & 6.2 & 0.4 \\
\hline $\mathrm{MgO}$ & 0.4 & 0.5 & 0.6 & 0.4 & 0.6 & 0.5 \\
\hline $\mathrm{K}_{2} \mathrm{SO}_{4}$ & - & - & 0.6 & - & 1.1 & - \\
\hline $\mathrm{CaSO}_{4} \cdot 2 \mathrm{H}_{2} \mathrm{O}$ & - & - & - & 0.4 & - & 0.6 \\
\hline $\mathrm{CaSO}_{4} \cdot 1 / 2 \mathrm{H}_{2} \mathrm{O}$ & 0.4 & - & 1.2 & - & 1.3 & - \\
\hline $\mathrm{CaSO}_{4}$ & - & - & - & 0.5 & - & - \\
\hline $\mathrm{Ca}(\mathrm{OH})_{2}$ & - & 0.7 & 3.7 & 0.6 & 2.6 & 2.4 \\
\hline $11 \mathrm{CaO} .7 \mathrm{Al}_{2} \mathrm{O}_{3} \cdot \mathrm{CaF}_{2}$ & - & - & - & - & - & 1.5 \\
\hline
\end{tabular}

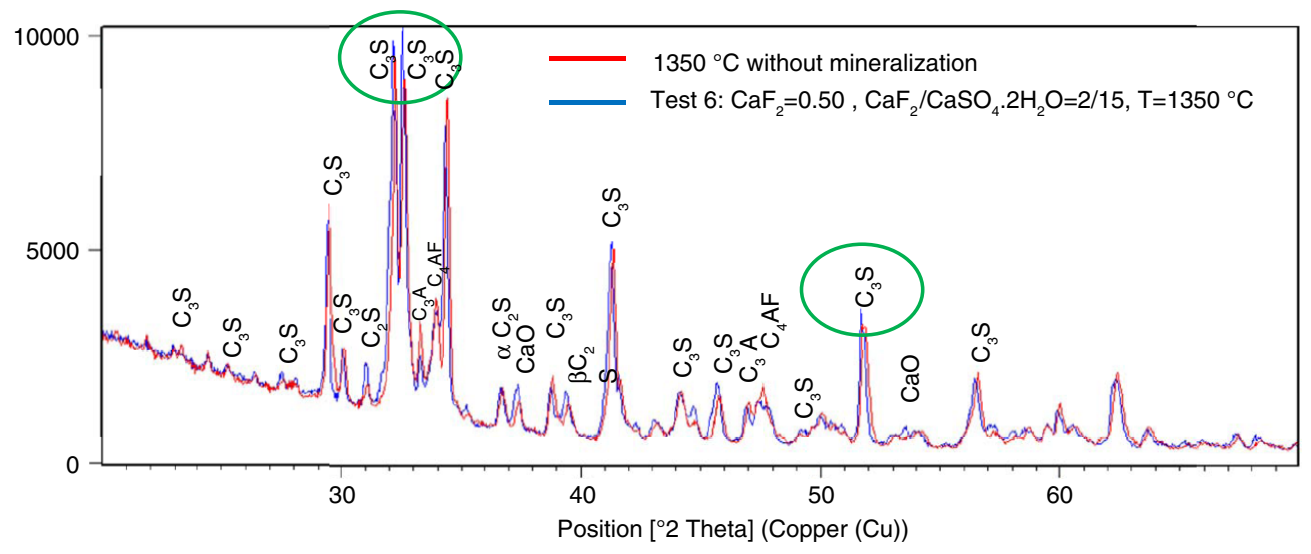

Figure 4. Diffraction patterns of raw mixture without mineralizer and test 6 mixture at $1350{ }^{\circ} \mathrm{C}$.

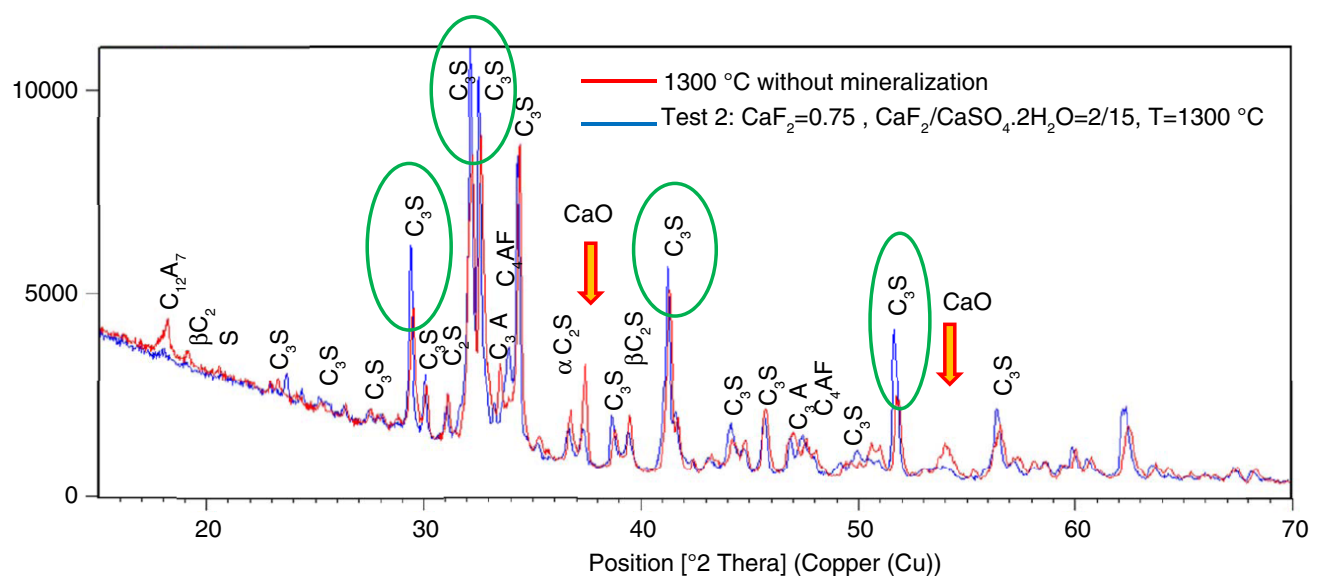

FIGURE 5. DRX of raw mixture without mineralizer and test 2 mixture at $1300^{\circ} \mathrm{C}$. 
Optimal fluorite/gypsum mineralizer ratio in Portland cement clinkering $\bullet 7$

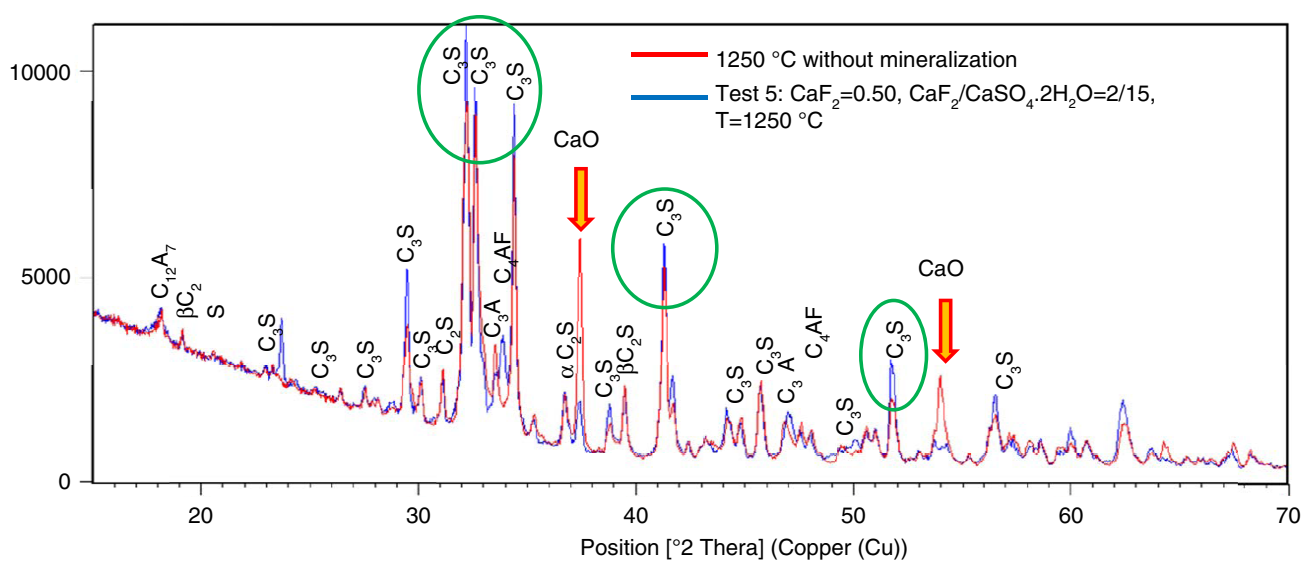

FIGURE 6. DRX of raw mixture without mineralizer and test 5 mixture at $1250{ }^{\circ} \mathrm{C}$.

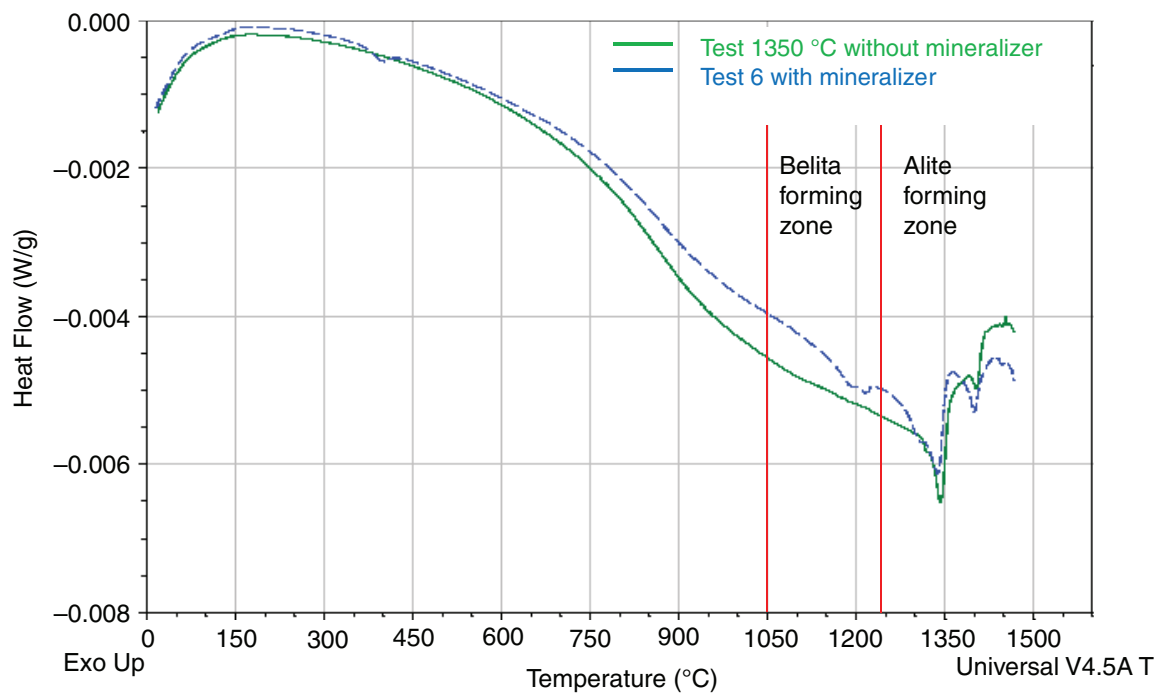

FIGURE 7. DSC of raw mixture without mineralizer and test 6 mixture at $1350{ }^{\circ} \mathrm{C}$.

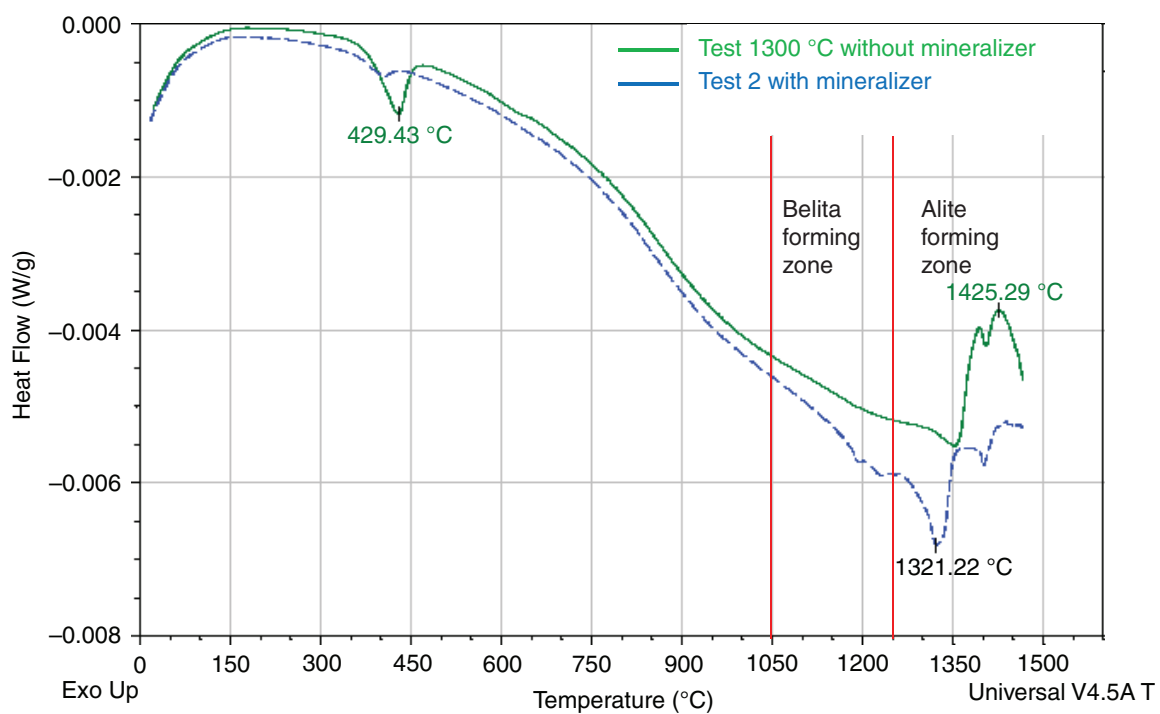

FIGURE 8. DSC of raw mixture without mineralizer and test 2 mixture at $1300{ }^{\circ} \mathrm{C}$. 


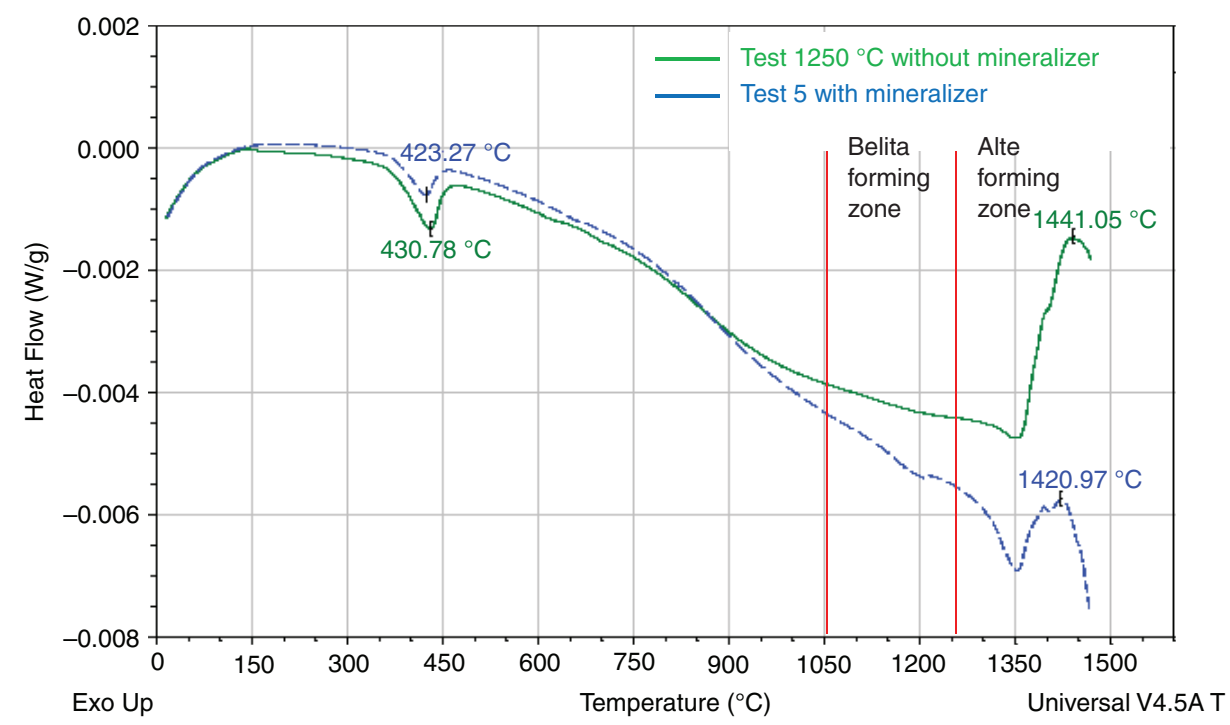

FIGURE 9. DSC of raw mixture without mineralizer and test 5 mixture at $1250{ }^{\circ} \mathrm{C}$.

(a)

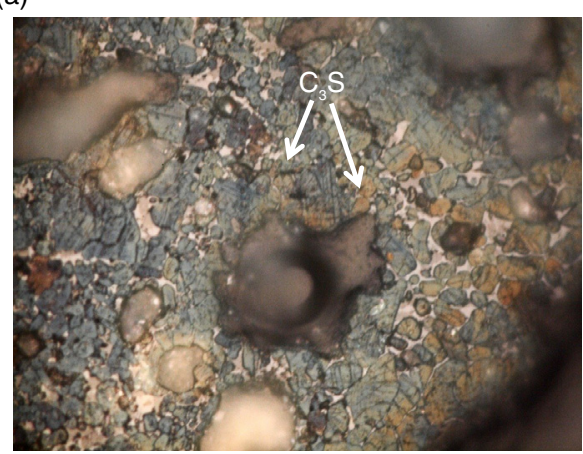

(c)

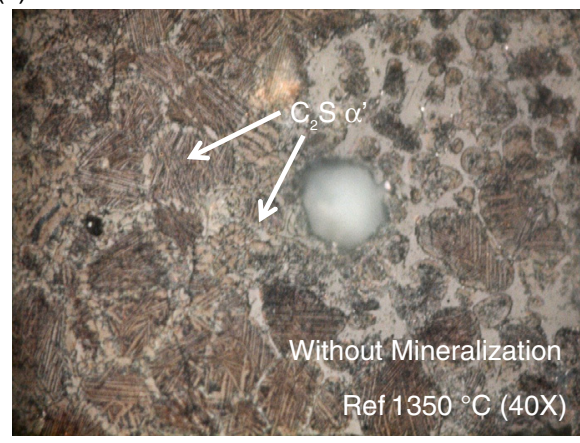

(b)

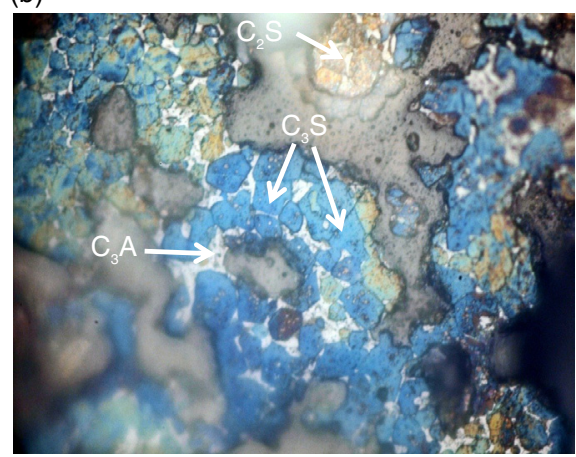

(d)

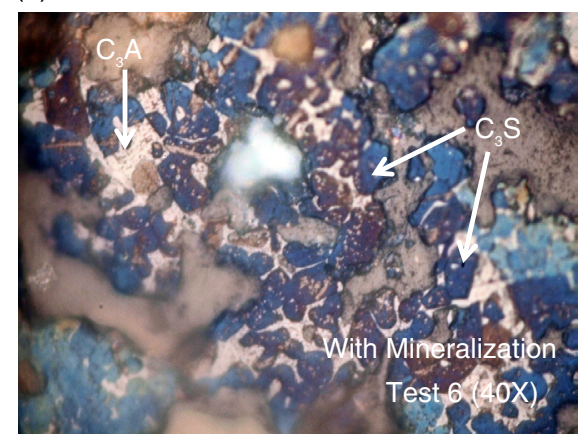

FIGURE 10. Petrographic comparison of mineralized clinker - test 6

(photographs b and d) and clinker without mineralizers (photographs a and c), at $1350{ }^{\circ} \mathrm{C}$.

\subsubsection{Optical Microscopy (Petrography)}

Figures 10, 11, and 12 show better-defined particles of calcium silicates and calcium aluminates in the mineralized clinker than in the clinker without mineralizers at the same temperature.
This indicates that the mineralizers had a positive effect on the clinkering process. The clinkering process at $1250{ }^{\circ} \mathrm{C}$ (Figure 12) requires a longer time or higher sintering temperature in order to achieve the complete formation of the clinker's phases. 
(a)

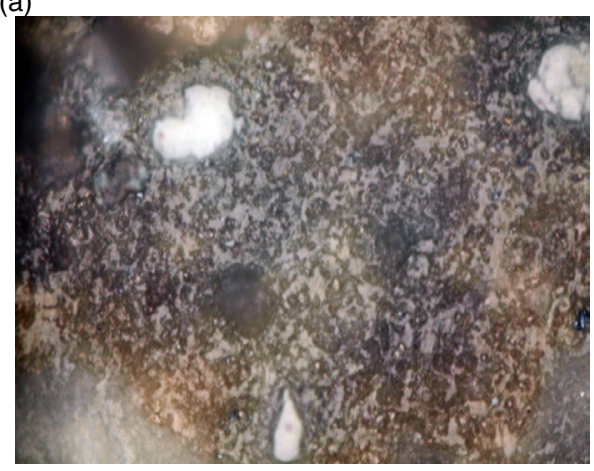

(c)

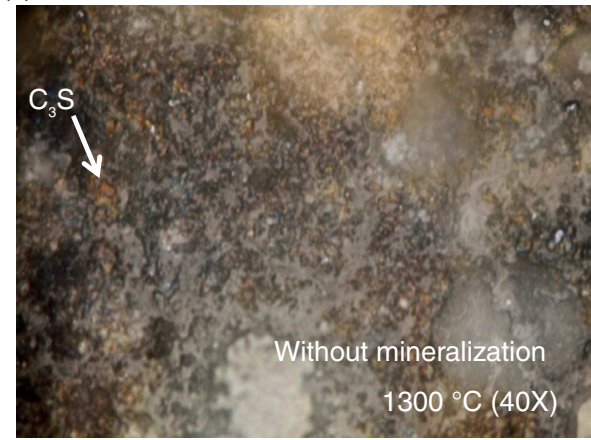

(b)

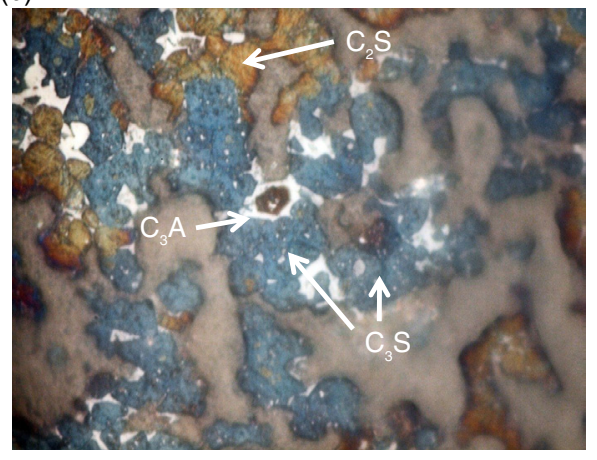

(d)

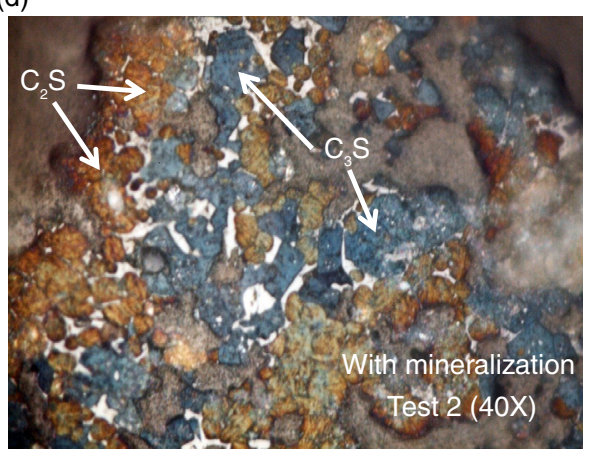

FIGURE 11. Petrographic comparison of mineralized clinker - test 2

(photographs b and d) and clinker without mineralizers (photographs a and c), at $1300{ }^{\circ} \mathrm{C}$.

(a)

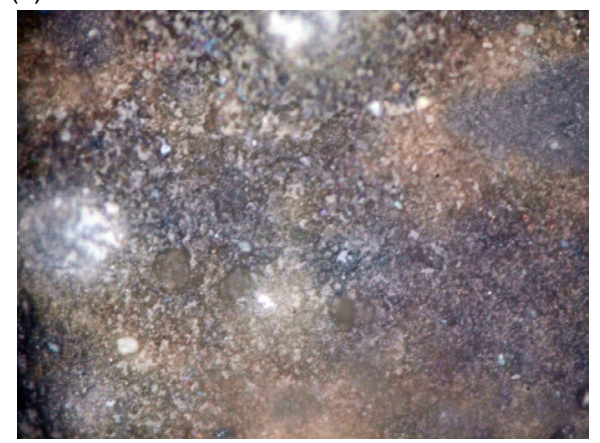

(c)

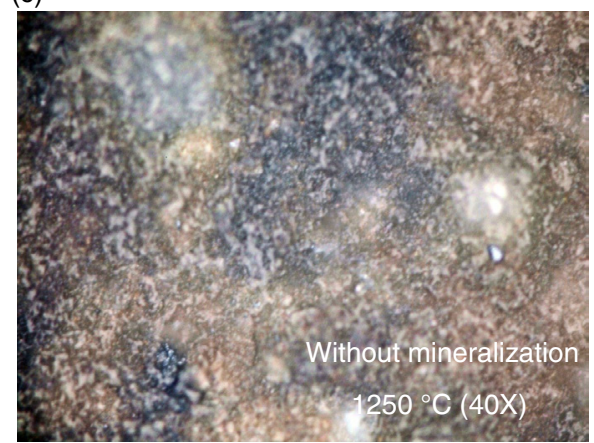

(b)

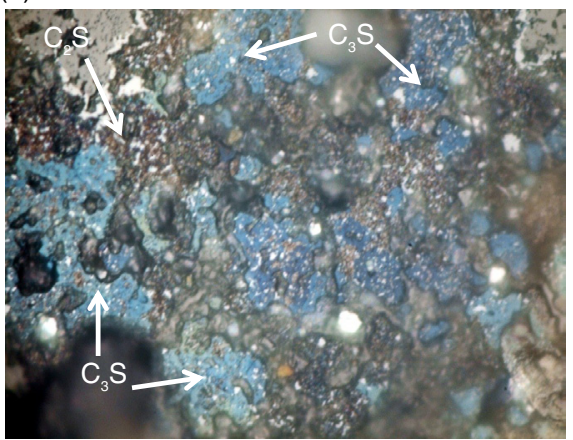

(d)

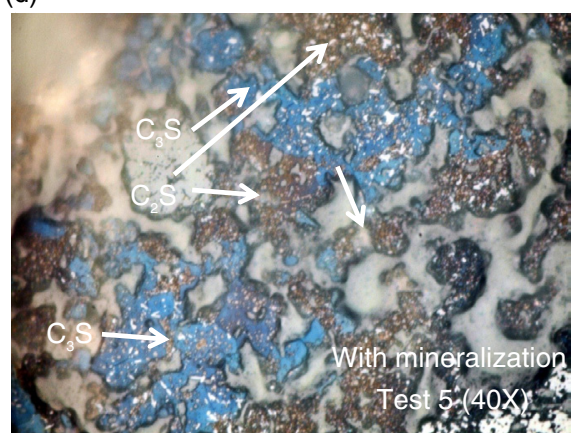

FIGURE 12. Petrographic comparison of mineralized clinker - test 5

(photographs b and d) and clinker without mineralizers (photographs a and c), at $1250{ }^{\circ} \mathrm{C}$. 
TABLE 5. Alite size

\begin{tabular}{lc}
\hline Sample & Alite size $(\boldsymbol{\mu m})$ \\
\hline Ref $1350{ }^{\circ} \mathrm{C}$ & 7.82 \\
Test 6 & 11.00 \\
Ref $1300{ }^{\circ} \mathrm{C}$ & $<7.00$ \\
Test 2 & 28.00 \\
Ref $1250{ }^{\circ} \mathrm{C}$ & $<7.00$ \\
\hline
\end{tabular}

An idiomorphic, equidimensional alite shape was obtained at a $\mathrm{CaF}_{2} / \mathrm{CaSO}_{4} \cdot 2 \mathrm{H}_{2} \mathrm{O}$ ratio of $2 / 15$ and a temperature greater than or equal to $1300{ }^{\circ} \mathrm{C}$ (tests 2 and 6 ). The clinker also had improved reactivity in these conditions because it obtained a reactive phase of belite as $\alpha^{\prime}$ and $\alpha$ at lower temperatures. In contrast, xenomorphic crystals with irregular shapes were observed in the clinker without mineralization, indicating a lack of clinkering. This result is consistent with those of researchers including GarcíaDíaz et al. (19), who found that $\mathrm{CaF}_{2}$ affected clinker phase content and polymorphism.

In regard to the assessment of alite size, the samples with mineralizers always presented larger alite sizes (Table 5). Test 2 reached a regular size
(28 micrometers) with evidence of a complete reaction and crystallization. Based on this, it can be concluded that the fluorite/gypsum ratio of $2 / 15$ works efficiently at $1300{ }^{\circ} \mathrm{C}$, allowing crystalline phases to form at a lower temperature.

Free $\mathrm{CaO}$ measurement in the clinker, XRD, DSC and optical microscopy were used to show that fluorite and gypsum have a significant effect at temperatures of $1300{ }^{\circ} \mathrm{C}$ and $1250^{\circ} \mathrm{C}$. It can be concluded that the fluorite/gypsum ratio of $2 / 15$ works efficiently at $1300{ }^{\circ} \mathrm{C}$, since the best results corresponded to that sample (the greatest amount of alite, the least belite, the smallest amount of free lime and regularly sized alite).

\subsubsection{Statistical model}

The R-programming language was used in the analysis and modeling of the Box-Behnken experimental design, because it has statistical packages to optimize the process variables. For this boundary, curves were generated to identify the trend of the variables studied. The results obtained in the simulation showed the same behavior as the experimental results. The behavior obtained (Figure 13) showed that increases in fluorite and temperature led
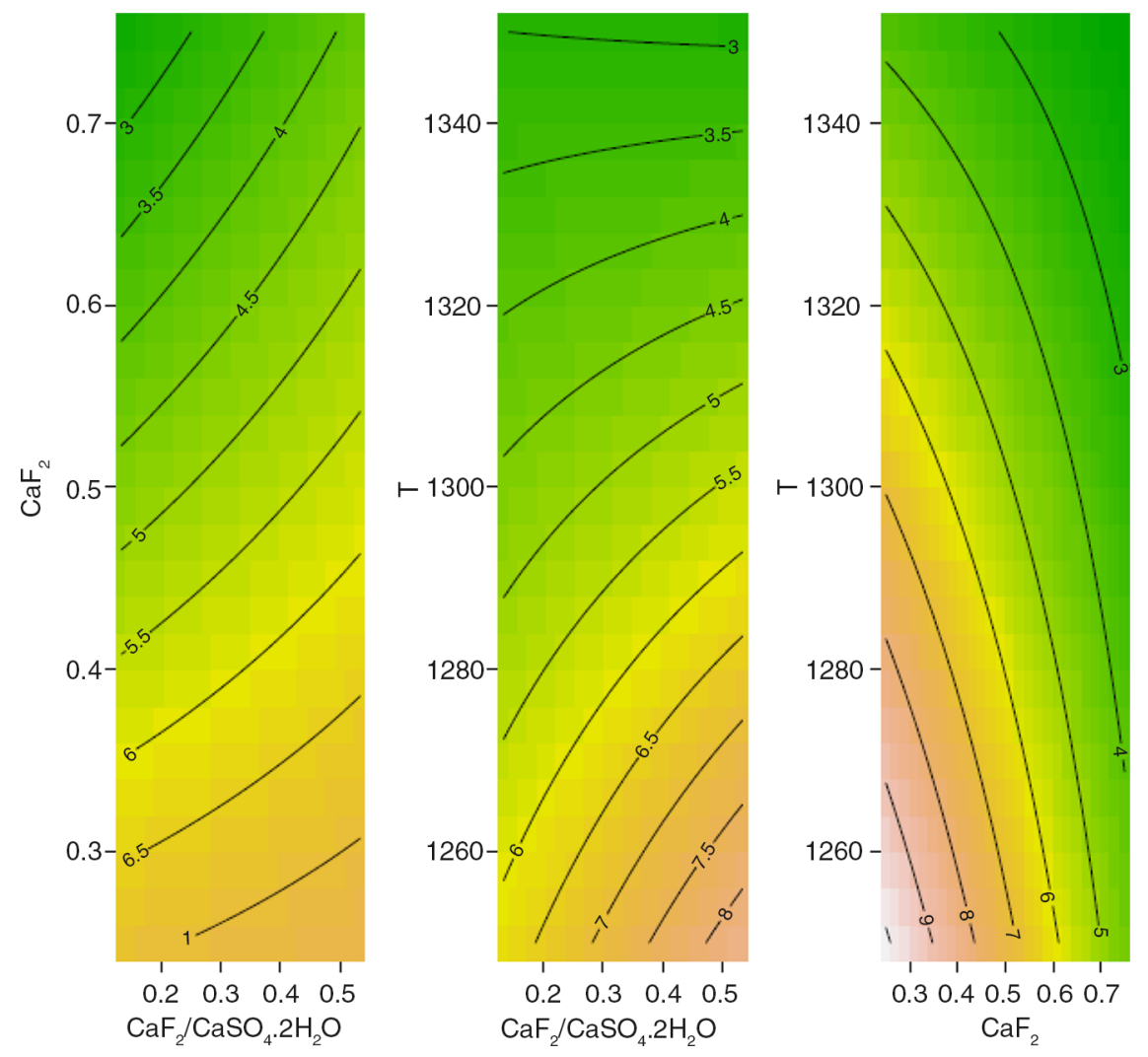

FIGURE 13. Boundary curves of the effect of fluorite, gypsum and temperature on free lime in the clinker. 
to decreased free lime in the clinker, while the lowest fluorite/gypsum ratio (2/15) improved clinkering (green areas).

\section{CONCLUSIONS}

By using fluorite and gypsum in the production of Portland cement clinker, it is possible to decrease the clinkering temperature, and thus reduce fuel consumption and emissions.

Petrographic analysis showed the appearance of calcium silicates and calcium aluminates at a lower temperature when mineralizers were incorporated into the raw materials.

The $\mathrm{CaF}_{2} / \mathrm{CaSO}_{4} \cdot 2 \mathrm{H}_{2} \mathrm{O}$ ratio of $2 / 15$ favored the production of idiomorphic alite in the appropriate particle size and amount and belite $\alpha$ and $\alpha$ ' in the mineralized clinker. It showed evidence of a reactive clinker. This could enable cement plants to increase mineral additions to the cement, which is another way to reduce costs and emissions associated with lower clinker consumption.

Mineralizers showed a positive effect on free $\mathrm{CaO}$ content in the clinker. At $1300{ }^{\circ} \mathrm{C}$ and $1250{ }^{\circ} \mathrm{C}$, all formulations with mineralization had less free $\mathrm{CaO}$ than the reference sample, which indicates efficient clinkering.

The clinker formulation presented in test 2 $\left(\mathrm{CaF}_{2} / \mathrm{CaSO}_{4} \cdot 2 \mathrm{H}_{2} \mathrm{O}=2 / 15\right.$, temperature $=1300{ }^{\circ} \mathrm{C}$, and fluorite $=0.75$ ) had an $81 \%$ reduction in free $\mathrm{CaO}$ compared to the clinker without mineralization at the same temperature. This ratio was the best formulation found, from an energy standpoint. This represents temperature savings of $150{ }^{\circ} \mathrm{C}$ compared to a conventional clinker $\left(1450{ }^{\circ} \mathrm{C}\right)$.

Fluorite and gypsum did not have a significant effect at a temperature higher than or equal to $1350{ }^{\circ} \mathrm{C}$.

\section{REFERENCES}

1. Taylor, H.F.W. (1990) Cement Chemistry, Academia Press, Inc. New York.

2. Hasanbeigi, A.; Price, L.; Lin, E. (2012) Emerging energyefficiency and $\mathrm{CO}_{2}$ emission-reduction technologies for cement and concrete production: A technical review. Renewable and Sustainable Energy Reviews 16, 6220-6238. http://dx.doi.org/10.1016/j.rser.2012.07.019.

3. Lawrence, C. (1988) Lea's chemistry of cement and concrete. Cap 9: Production of Low-Energy Cements. $4^{\text {th }}$ ed.

4. Chatterjee, A.K. (2011) Chemistry and engineering of the clinkerization process - Incremental advances and lack of breakthroughs. Cem. Concr. Res. 41, 624-641. http://dx.doi. org/10.1016/j.cemconres.2011.03.020.

5. Van Oss, HG.; Padovani, A.C. (2003) Cement manufacture and the environment, part II: environmental challenges and opportunities. J. Ind. Ecol. 7, 93-126. http://dx.doi.org/ $10.1162 / 108819803766729212$

6. Puertas, F.; García-Díaz, I.; Barba, A.; Gazulla, M.F.; Palacios, M.; Gómez, M.P.; Martínez-Ramírez, S. (2008) Ceramic wastes as alternative raw materials for Portland cement clinker production. Cem. Concr. Comp. 30, 798-805. http://dx.doi.org/10.1016/j.cemconcomp.2008.06.003.

7. Garnet, E. (2004) Industrially interesting approaches to "low $\mathrm{CO}_{2}$ " cements. Cem. Concr. Res. 34,1489-98. http:// dx.doi.org/10.1016/j.cemconres.2004.01.021.
8. World Business Council for Sustainable Development (WBCSD)/International Energy Agency (IEA). (2009a) Cement Technology Roadmap 2009-Carbon emissions reductions up to 2050. Available: www.iea.org/papers/2009/ Cement_Roadmap.pdfS.

9. Gineys, N.; Aouad, G.; Sorrentino, F.; Damidot, D. (2011) Incorporation of trace elements in Portland cement clinker: Thresholds limits for $\mathrm{Cu}, \mathrm{Ni}, \mathrm{Sn}$ or $\mathrm{Zn}$. Cem. Concr. Res. 41, 1177-1184. http://dx.doi.org/10.1016/j.cemconres. 2011.07.006

10. García-Díaz, I.; Palomo, J.G.; Puertas, F. (2011) Belite cements obtained from ceramic wastes and the mineral pair $\mathrm{CaF}_{2} / \mathrm{CaSO}_{4}$. Cem. Concr. Comp. 33, 1063-1070. http:// dx.doi.org/10.1016/j.cemconcomp.2011.06.003.

11. Ying-Liang Chen; Juu-En Chang; Pai-Haung Shih; Ming-Sheng Ko; Yi-Kuo Chang; Li-Choung Chiang. (2010) Reusing pretreated desulfurization slag to improve clinkerization and clinker grindability for energy conservation in cement manufacture. J. Env. Manag. 91, 1892-1897. http://dx.doi.org/10.1016/j.jenvman.2010.04.006.

12. Emanuelson, A.; Hansen, S.; Viggh, E. (2003) A comparative study of ordinary and mineralised Portland cement clinker from two different production units Part I: Composition and hydration of the clinkers. Cem. Concr. Res. 33 [10] 1613-1621. http://dx.doi.org/10.1016/S0008-8846(03)00115-7.

13. Emanuelson, A.; Landa-Cánovas, A.; Hansen, S. (2003) A comparative study of ordinary and mineralized Portland cement clinker from two different production units Part II: Characteristics of the calcium silicates. Cem. Concr. Res. 33, 1623-1630. http://dx.doi.org/10.1016/S0008-8846(03) 00114-5.

14. Tongsheng Zhang; Xiangyang Liu; Jiangxiong Wei; Qijun Yu. (2014) Influence of preparation method on the performance of ternary blended cements. Cem. Concr. Comp. 52, 18-26. http://dx.doi.org/10.1016/j.cemconcomp.2014.04.005.

15. Komnitsas, K: Zaharaki, D (2007) Geopolymerisation: A review and prospects for the minerals industry. Minerals Engineering. 20, 1261-1277. http://dx.doi.org/10.1016/j. mineng.2007.07.011.

16. Péra, J.; Ambroise, J. (2004) New applications of calcium sulfoaluminate cement. Cem. Concr. Res. 34, 671-676. http:// dx.doi.org/10.1016/j.cemconres.2003.10.019.

17. Ghafari, E.; Costa, H.; Júlio, E.; Portugal, A.; Duraes, L. (2014) The effect of nanosilica addition on flowability, strength and transport properties of ultra high performance concrete. Mat. Design. 59, 1-9. http://dx.doi.org/10.1016/j. matdes.2014.02.051.

18. Moir, G.K.; Glasser, F.P. (1992) Mineralisers, modifiers and activators in the clinkering process, Proceedings of the 9th International Congress on the Chemistry of Cement, New Delhi 1992, vol. 1, National Council for Cement and Building Materials, New Delhi, 25-152.

19. Stephan, D * Mallmann, R.; Knöfel, D ; Härdtl, R (1999) High intakes of $\mathrm{Cr}, \mathrm{Ni}$, and $\mathrm{Zn}$ in clinker art I. Influence on burning process and formation of phases. Cem. Concr. Res. 29, 1949-1957. http://dx.doi.org/10.1016/S0008-8846 (99)00195-7.

20. Kolovos, K.; Tsivilis, S.; Kakali, G. (2002) The effect of foreign ions on the reactivity of the $\mathrm{CaO}-\mathrm{SiO}_{2}-\mathrm{Al}_{2} \mathrm{O}_{3}-\mathrm{Fe}_{2} \mathrm{O}_{3}$ system Part II: Cations. Cem. Concr. Res. 32, 463-469. http://dx.doi.org/10.1016/S0008-8846(01)00705-0.

21. Trezza, M.A.; Scian, A.N. (2007) Waste with chrome in the Portland cement clinker production. J. Haz. Mat. 147, 188-196. http://dx.doi.org/10.1016/j.jhazmat.2006.12.082.

22. Xian-Wei Ma; Hu-Xing Chen; Pei-Ming Wang. (2010) Effect of $\mathrm{CuO}$ on the formation of clinker minerals and the hydration properties. Cem. Concr. Res. 40, 1681-1687. http://dx.doi.org/10.1016/j.cemconres.2010.08.009.

23. Kacimi, L.; Simon-Masseron, A.; Ghomari, A.; Derriche, Z. (2006) Reduction of clinkerization temperature by using phosphogypsum. J. Haz. Mat. B137, 129-137. http://dx.doi. org/10.1016/j.jhazmat.2005.12.053.

24. Kacimi, L.; Simon-Masseron, A.; Ghomari, A.; Derriche, Z (2006) Influence of $\mathrm{NaF}, \mathrm{KF}$ and $\mathrm{CaF}_{2}$ addition on the clinker burning temperature and its properties. C. R. Chimie. 9 , 154-163. http://dx.doi.org/10.1016/j.crci.2005.10.001. 
25. Syal, S.K.; Kataria, S.S. (1981) Optimization of burning characteristics of raw meal for fuel economy by special mineralizer. World cement technology.12 [6], 279-285.

26. Restrepo, O.I.; Tobón, J.I.; Restrepo, O.J. (2007) Efecto de algunas adiciones minerales colombianas en la fabricación de clínker para cemento Pórtland I. Dyna. 74 [152], 263-674.

27. Kolovos, K.; Loutsi, P.; Tsivilis, S.; Kakali, G. (2001) The effect of foreign ions on the reactivity of the $\mathrm{CaO}-\mathrm{SiO}_{2-}$ $\mathrm{Al}_{2} \mathrm{O}_{3}-\mathrm{Fe}_{2} \mathrm{O}_{3}$ system Part I. Anions. Cem. Concr. Res. 31 , 425-429. http://dx.doi.org/10.1016/S0008-8846(00)00461-0.

28. Akin A.I. (1999) Effect of $\mathrm{CaF}_{2}$ and $\mathrm{MgO}$ on sintering of cement clinker. Cem. Concr. Res. 29, 1847-1850. http:// dx.doi.org/10.1016/S0008-8846(99)00151-9.

29. Schoon, J.; Vergari, A.; De Buysser, K.; Van Driessche, I.; De Belie, N. (2013) Fines extracted from porphyry and dolomitic limestone aggregates production: $\mathrm{MgO}$ as fluxing agent for a sustainable Portland clinker production. Construc. Build. Mat. 43, 511-522. http://dx.doi.org/ 10.1016/j.conbuildmat.2013.02.046.

30. Blanco, M.T.; Puertas, F.; Vazquez, T.; Palomo. A. (1996) Modelling of the burnability of white cement raw mixes made with $\mathrm{CaF}_{2}$ and $\mathrm{CaSO}_{4}$. Cem. Concr. Res. 26 [3], 457-464.http://dx.doi.org/10.1016/S0008-8846(96)85033-2.

31. Blanco-Varela, M.T.; Palomo, A.; Puertas, F.; Vázquez, T. (1995) Influencia de la incorporación conjunta del $\mathrm{CaF}_{2}$ y del $\mathrm{CaSO}_{4}$ en el proceso de clinkerización. Obtención de nuevos cementos. Mater. Construcc. 45 [239], 29-47. http:// dx.doi.org/10.3989/mc.1995.v45.i239.551.
32. Dominguez, O.; Torres-Castillo, A.; Flores-Velez, L.M.; Torres, R. (2010) Characterization using thermomechanical and differential thermal analysis of the sinterization of Portland clinker doped with $\mathrm{CaF}_{2}$. Materials Characterization. 61, 459-466. http://dx.doi.org/10.1016/j.matchar. 2010.02.002.

33. Murray, R.J.; Brown, A.W. (1978) Improvements in Hydraulic Cements, U.K. Patent no. 1498057.

34. Grillo-Renó, M.L; Martins-Torres, F; Da Silva, R.J.; Conceição Soares Santos, J.J.; Motta Melo, M. (2013) Exergy analyses in cement production applying waste fuel and mineralizer. Energy Conversion and Management. 75, 98-104. http://dx.doi.org/10.1016/j.enconman.2013. 05.043 .

35. Blanco-Varela, M.T.; Vázquez, T. (1981) Ahorro de energía en la clinkerización empleando $\mathrm{CaF}_{2} \mathrm{y} \mathrm{CaSO}_{4}$ como mineralizadores. Estudio de la fluorellestadita $\left(3 \mathrm{C}_{2} \mathrm{~S} \cdot \mathrm{CaSO}_{4} \cdot \mathrm{CaF}_{2}\right)$. Mater. Construcc. 181, 55-64. http://dx.doi.org/10.3989/mc. 1981.v31.i181.1020.

36. Giménez-Molina S.; Blanco-Varela, MT. (1995) Solid state phases relationship in the $\mathrm{CaO}-\mathrm{SiO}, \mathrm{Al}_{2} \mathrm{O}, \mathrm{CaF}_{2}$ $\mathrm{CaSO}_{4}$ system. Cem Concr Res. 25, 870-82. http://dx.doi. org/10.1016/0008-8846(95)00078-Q.

37. Gartner, E.; Hirao, H. (2015) A review of alternative approaches to the reduction of $\mathrm{CO}_{2}$ emissions associated with the manufacture of the binder phase in concrete. Cem. Concr. Res. 78, Part A, 126-142. http://dx.doi.org/10.1016/j. cemconres.2015.04.012. 